\title{
Análise sobre a (não) caracterização do crime de racismo no Tribunal de Justiça de São Paulo
}

Analysis of the (non) characterization of the crime
of racism in São Paulo Court of Justice

Simone Becker e Deborah Guimarães Oliveira

\section{Introdução}

O presente trabalho é resultado de pesquisas por nós realizadas nos últimos três anos, ligadas ao projeto "Maiorias que são minorias, invisíveis que (não) são dizíveis: etnografias sobre sujeitos à margem dos discursos dominantes", e ao Programa Institucional Voluntário de Iniciação Científica (PIVIC) “Negro sujo, macaco, vagabundo e sem vergonha': quando os insultos verbais desferidos aos negros ofendem ao indivíduo e não ao seu pertencimento étnico". ${ }^{1}$

Simone Becker é doutora em Antropologia Social pela Universidade de Santa Catarina. É diretora da Faculdade de Direito e Relações Internacionais e docente permanente do Programa de Pós-Graduação em Antropologia Sociocultural da Universidade Federal da Grande Dourados (UFGD), Dourados, Mato Grosso do Sul, Brasil (simonebk@yahoo.com.br).

Deborah Guimarães Oliveira é graduanda em Direito na UFGD (deborah_dgo@hotmail.com). Artigo recebido em 25 de junho e aprovado para publicação em 10 de setembro de 2013.

Est. Hist., Rio de Faneiro, vol. 26, no 52, p. 451-470, julho-dezembro de 2013. 


\section{Simone Becker e Deborah Guimarães Oliveira}

Durante esse período, dedicamo-nos (em parte) à compreensão dos argumentos que levaram alguns discursos jurídicos do Tribunal de Justiça de São Paulo (TJSP) a (não) criminalizar como racismo condutas ofensivas a negros. De certa forma, esses argumentos estão imiscuídos do "mito da democracia racial" (Freyre, 1998), responsável em grande medida pela visão de muitos de que não existe racismo no Brasil, haja vista a convivência cordial entre brancos, negros e índios (Leite, 1996). Por outro lado, lembramos que o racismo é declarado crime "imprescritível"2 e "inafiançável"3 pela Constituição Federal de 1988 em seu artigo $5^{\circ}$, inciso XLII, e que tal crime está devidamente regulamentado ou detalhado na Lei 7.716/89, apelidada de Lei Caó em homenagem a seu idealizador, o parlamentar Carlos Alberto Caó.

Como parte dos projetos por nós desenvolvidos, nos ocupamos inicialmente, em especial entre os anos de 2010 e 2011, da análise de julgamentos referentes ao crime de racismo produzidos pelo Tribunal de Justiça do Estado do Rio Grande do Sul (TJRS). Cabe um breve retrospecto dos aspectos gerais dessa análise, de acordo com a perspectiva antropológica pautada na comparação (Dumont, 1997: 50), que guia nosso olhar analítico sobre o TJSP.

No tribunal gaúcho, buscamos a compreensão em profundidade de dois acórdãos ${ }^{4}$ que desclassificavam denúncias de crime de racismo para injúria qualificada com teor de ofensa racial, tendo como pano de fundo o fato de o Rio Grande do Sul ser considerado no plano ideal como progressista em seus posicionamentos, graças, em grande medida, ao movimento que em solos brasileiros se tornou conhecido na década de 1980 como "direito alternativo". 5

Examinando os discursos jurídicos nos dois julgados do TJRS, observamos que o argumento central da desclassificação do crime de racismo para injúria qualificada com teor de ofensa étnica residiu na justificativa de que os insultos verbais não eram racistas por não atingirem "a coletividade da raça negra", mas apenas "a honra subjetiva do ofendido". Sugerimos que tal lógica jurídica desconsiderava ser a honra o reflexo da inserção do sujeito nos seus diversos contextos sociais relacionais, já que a própria noção sociológica e antropológica de honra, tal como sustentam os teóricos que se dedicaram ao contexto mediterrâneo, equivale justamente àquilo que nos faz pertencer ou não a um dado grupamento social (Pitt-Rivers, 1979; Bourdieu, 1971; Fonseca, 2000; Becker, 2002).

Dessa forma, como bem reitera Emerson Rocha (2009) em sua pesquisa com mulheres jovens negras, não é possível desatar a honra subjetiva do negro da coletividade da qual ele faz parte, na medida em que a própria conceituação do que se convenciona chamar de honra está enraizada no sentimento de pertença a determinada categoria social ou grupo étnico-racial. Nesse sentido, inspirando-nos em Antonio Sérgio Alfredo Guimarães (2003), tanto em relação ao termo 
"raça" quanto em relação ao termo "honra", não há como desvincularmos as noções enquanto categorias analíticas e êmicas. E mais: uma das polêmicas ligadas à desclassificação do crime de racismo previsto na Lei 7.716/89 para o constante desde 1997 no Código Penal - que define a injúria qualificada pelo teor racial -é que a reforma deveria ter sido feita com o acréscimo dessa modalidade de xingamento racial no próprio corpo da Lei Caó. Sua não inserção retira desse "tipo penal" o caráter de prática de um crime de racismo (Panice, 2009).

\section{A escolha do TJSP: aspectos metodológicos}

Tecidas as ponderações quanto às não condenações por crime de racismo no TJRS, passemos à análise do conteúdo explorado no TJSP. A pesquisa centrou-se no estado de São Paulo por motivos pontuais e precisos.

Inicialmente, há que ressaltar que o Ministério Público no estado de São Paulo ao longo da década de 1980 foi responsável pelo movimento que culminou na aprovação do projeto de lei da ação civil pública, de 1985 (Silva, 2001). Cabe ainda destacar que a "ação civil pública" é a responsável pela defesa dos chamados direitos difusos e direitos coletivos, algo que concedeu imensa acessibilidade à justiça por parte dos grupos minoritários (Silva, 2001; Arantes, 1999), tornando o Ministério Público responsável pela defesa da sociedade. Nas palavras de Cátia Aida Silva (2001:128):

É preciso dizer que os membros da instituição, especialmente do Ministério Público do Estado de São Paulo, contribuíram de forma decisiva para a introdução de leis de proteção aos interesses metaindividuais no Brasil.

A escolha do TJSP se deu pelo fato de que o estado de São Paulo compõe, juntamente com o do Mato Grosso do Sul, o Tribunal Regional Federal da $3^{\mathrm{a}} \mathrm{Re}-$ gião (TRF-3 $3^{a}$ Região). Como, na estrutura do Judiciário federal, o estado do Mato Grosso do Sul vincula-se ao estado de São Paulo, partimos do pressuposto de que existe a tendência de o Judiciário do Mato Grosso do Sul, talvez também na esfera estadual, seguir o de São Paulo - mas não necessariamente, mesmo porque há distinções entre as esferas estadual e federal, seja pelas matérias julgadas, seja pelas trajetórias dos sujeitos que as compõem (Sadek, 2006; Vianna, 1997). Consideramos também que no processo de ocupação do sul do então estado de Mato Grosso, atual Mato Grosso do Sul, houve um importante fluxo migratório paulista, com influência no projeto colonizador da região ${ }^{6}$ (Bonfim, 2009). 


\section{Simone Becker e Deborah Guimarães Oliveira}

Feitas todas estas considerações, nos deslocamos para a metodologia empregada ao longo da pesquisa. No dia 3 de dezembro de 2011, digitamos no site do TJSP (www.tj.sp.gov.br), no item jurisprudência livre, a palavra-chave "crime de racismo", para filtrarmos quantos foram os julgamentos relacionados a esta keyword. Assim vieram à tela 599 acórdãos. Frente ao elevado número de julgamentos e à impossibilidade de analisarmos seus discursos em uma pesquisa cuja metodologia é qualitativa e não quantitativa, retornamos ao buscador com outra palavra-chave. Digitamos "condenação crime de racismo" e obtivemos 321 acórdãos. Deste último resultado separamos os julgamentos relativos à área criminal, e obtivemos 249 acórdãos.

Tendo em vista que o objetivo central deste trabalho é analisar se o TJSP condena ou não pelo crime de racismo, do resultado de 249 acórdãos foram destacadas as "apelações". Lembramos que uma apelação é uma espécie de "recurso" ou expressão de indignação posta no papel contra a primeira decisão que põe fim provisório ao conflito. Assim, a parte vencida ou "apelante", inconformada com a decisão judicial, interpõe o recurso de apelação (ou o pedido de reexame) ao órgão hierarquicamente superior ao primeiro juiz que produziu o julgamento. Uma vez que somente aqueles documentos que põem fim ao conflito e, portanto, condenam ou absolvem interessavam a esta pesquisa, destacamos, dos 249 acórdãos, 39 apelações.

Dessas 39 apelações, finalmente, recortamos apenas 9 (ver Anexo), pois as outras 30 não se referiam ao crime de racismo propriamente dito. Isto é, o seletor do buscador do TJSP as selecionou por fazerem menção indireta, mas não direta, como desejávamos, ao crime de racismo. Feito isto, as 9 apelações objeto desta pesquisa foram lidas e analisadas pormenorizadamente. A partir da análise de discurso foi feito um quadro comparativo com os principais argumentos que se repetiam entre as apelações. Pedimos ao leitor que retenha esta informação, a saber, que o critério para o rastreamento da análise de discurso dos julgamentos foi a repetição de justificativas que condenavam ou absolviam os réus por crime de racismo. Para partirmos rumo às análises, resta esclarecer quais foram ou quais são essas repetições: "Crimes formais, dolo e provas"; "Honra subjetiva x Honra coletiva" e "Substituição de penas".

Finalmente, importa sublinhar que neste artigo nos preocuparemos em analisar as repetições atinentes ao dolo e à culpa e indiretamente aos crimes formais, classificação nativa à qual os crimes de racismo pertencem. Mas não se trata apenas de nos centrarmos nas repetições desses termos (categorias êmicas do discurso jurídico), que tendem a absolver e a condenar determinados sujeitos por crimes de racismo. Trata-se de perceber, à la Michel Foucault, como esse poderoso discurso que produz sujeitos, que é o discurso jurídico, articula a representação do racismo no contexto paulista: 
Trata-se para Foucault, então, de rastrear como estes diversos discursos (científicos ou não), apesar de muitas vezes contraditórios entre si, convergem para a elaboração de "enunciados" (o que é efetivamente "dito" ou "escrito") que sustentam a produção de saberes poderes. (Becker, 2008: 26)

Sob essa perspectiva nos ativemos à ordem restrita do discurso posto em escrito, a fim de compreendermos como a "verdade" singularizada dos sujeitos "vítima" e "autor", assim denominados pela lógica jurídica, é produzida tendo como norte a categoria raça, englobante da etnia na legislação que define o crime de racismo.

Por fim, esclarecemos que em nossa análise, como diante de "aldeias/arquivos" (Carrara, 1998; Becker, 2008), aproximamos o método do etnógrafo do métier do historiador. Se classicamente a etnografia é entendida como a metodologia adotada pelo antropólogo que "esteve lá", na convivência com seus "informantes/nativos", após décadas do legado de Bronislaw Malinowski (1978) tal perspectiva sofreu significativas modificações. Seu acento maior reside na produção da escritura que advém das observações do etnógrafo, esteja ele debruçado sobre fontes documentais ou não. Afinal, ou no final das contas, o que é o diário de campo, senão um espécime documental particular? "De mais a mais, os discursos dos quais emanam emoções, feitos, ditos, estejam eles nos arquivos ou in loco, refletem 'representações de representações de representações"' (Leite apud Becker, 2008: 20).

\section{Dolo e provas: argumentos que absolvem no TJSP}

Para entendermos as repetições rumo à (des)caraterização do crime de racismo no TJSP postas no "dolo" e nas "provas", temos que esmiuçar a lógica de ambos os termos para o discurso "doutrinário"7 jurídico e legal.

São elas: as trocas linguísticas assimétricas que sustentam os processos judiciais; a importância dos operadores do direito na produção das verdades e das provas judiciais, em especial, a do magistrado; os mecanismos de controle e de vigilância judiciais processuais que também são verificáveis em outros contextos (relacionais) sociais, e o poder exclusivo que os discursos sentenciais detêm de constituírem sujeitos (Becker, 2008: 265). 


\section{Simone Becker e Deborah Guimarães Oliveira}

Com relação ao poder imenso que somente o discurso jurídico detém, que é o de produção de nós sujeitos, podemos vinculá-lo aos efeitos do jargão jurídico de que "só existe para o contexto jurídico a realidade demonstrada nos autos do processo" (Becker, 2008: 265). Esta expressão advinda do latim atrela-se por sua vez às principais características que só o discurso jurídico detém, tais como: a utilização do método indutivo que desemboca em julgamentos anacrônicos (sincrônicos) e descontextualizados; a proliferação de sentenças que (re)produzem representações; e a instituição de consequências concretas quanto à produção de verdades que implicam - em alguma medida - a produção de sujeitos de carne e osso e de seus habitus (Bourdieu, 1996).

No que diz respeito às trocas linguísticas, à importância dos advogados, do magistrado e dos mecanismos de controle, tornam-se providenciais certos lembretes:

Cabe ao advogado, representante do autor de uma ação, iniciar as trocas processuais expondo ao magistrado o máximo de informações acerca dos objetivos de seu cliente, sob pena de sua petição inicial ser considerada pelo juiz como inepta - ou não passível de prosseguimento (Becker, 2008: 266).

Desta forma, é da competência do advogado que representa seu cliente, isto é, que o coloca novamente em um dado e determinado "presente" que já passou, e ao qual ele não esteve presente, definir com muita clareza e precisão, na parte do documento por ele produzido e denominada "pedidos", todas as demandas de seu representado. Mas não basta expor seus pedidos, sem que estes estejam devidamente referenciados à materialidade e à concretude do que, no discurso jurídico e legal, se intitula "provas". Assim,

cabe ao advogado do autor (ou requerente) mostrar ou indicar ao magistrado os indícios probatórios que refletem a veracidade de suas informações para basear os fatos que constituem seu direito (Becker, 2008: 266).

Afinal, só existe no e para o mundo fático das ciências jurídicas aquilo que está nos "autos de um processo". Sob esse prisma, se ao advogado da "vítima" de um crime compete esmiuçar seus pedidos e mostrar ao magistrado, responsável pela escolha da verdade que mais o convenceu, a materialidade de cada um dos pedidos, o mesmo se estende ao advogado do "réu”. Este deverá se ater à 
contestação ou refutação de cada ponto suscitado pelo representante da vítima, sob pena de o ponto não contestado ser tomado como verdade (singular). Além disso, ele pode e deve alegar novos fatos sobre o conflito, capazes de modificar, impedir e/ou inviabilizar os pedidos elaborados pela vítima. Como demonstra a posição de um magistrado quanto à estratégia do advogado de defesa da autora de uma ação cível:

$\mathrm{Na}$ versão da autora, ficou detalhado apenas seu reclamo de forma duvidosa quanto à própria existência dos fatos, ou seja, uma situação fantasiosa, ante os elementos trazidos. As suas testemunhas apontaram apenas a questão emocional, isto é, que a autora chorava e estava nervosa, quando relatou os fatos para suas professoras, sendo que estas, em juízo, sequer identificaram a ação ilícita, supostamente existente e apontada ao réu (Becker, 2008: 268).

Em síntese, para fecharmos estes lembretes:

Tanto na qualidade de advogado do réu quanto na do autor, cabe ao citado operador do Direito produzir desde o início do processo uma narrativa coerente, capaz de ser enriquecida ao longo de seu transcurso, seja por provas novas (ou inexistentes no momento da propositura da ação ou de sua contestação), seja pela ressignificação atribuída às provas juntadas aos autos do processo pelo adversário. Afinal, as coisas em si - documentos, telegramas, recibos, confissões, depoimentos, testemunhos - de nada valem sem o seu respectivo discurso e/ou interpretação. Se preferirmos Roland Barthes: "le fait n'a jamais qu'une existence linguistique" (apud Ginzburg, 2006: 219)(Becker, 2008: 268).

Aterrissemos na questão probatória e mergulhemos nos 9 acórdãos do TJSP. A coerência do "conjun to probatório" emerge, por exemplo, no acórdão ${ }^{\circ}$ III. Neste, Oscar Krool Filho, acusado de praticar racismo tal como prevê o artigo 20 da Lei 7.716/89, dirigiu-se ao segurança de um shopping menosprezando-o por ter permitido a entrada no estabelecimento de um adolescente negro. Por não ter retirado a acusação contra o réu, a vítima foi demitida do shopping. A condenação do réu por ter ofendido uma "coletividade" pela cor que porta foi destacada por uma das desembargadoras, não o relator, da seguinte forma:

Frise-se que o delito consiste no ato de executar uma manifestação racista, como a que foi realizada pelo réu, consoante a pro- 


\section{Simone Becker e Deborah Guimarães Oliveira}

va produzida, sem contradição ou mesmo oposição, não sendo necessária qualquer demonstração de condução de vida nesse sentido - racista por parte do incriminado em outras ocasiões. (TJSP, 2012a: 3).

Eis que desembocamos na diferenciação do que, para o discurso êmico do direito e da lei, são o "dolo", a "culpa", o "crime formal" e o "crime material". Essa diferenciação torna-se importante para que compreendamos em qual classificação o discurso doutrinário encaixa os crimes de racismo e quais são as estratégias argumentativas que os magistrados do TJSP utilizam para condenar ou absolver alguém a quem se imputam tais delitos.

Como explicado acima, quando se afirma que um sujeito cometeu crime de racismo, há que se provar, isto é, mostrar com materialidade/concretude que o suposto réu cometeu a ação descrita como delituosa e prevista em detalhes pela Lei Caó. Constitui crime de racismo, segundo o artigo 20 da Lei 7.716 de 1989: "Praticar, induzir ou incitar a discriminação ou preconceito de raça, cor, etnia, religião ou procedência nacional". A pena é de reclusão de um a três anos e multa, e, para que seja aplicada, a intenção de praticar o crime (ou "dolo") deve ser provada. E se o incitamento ou a indução à discriminação ou ao preconceito se fizerem por palavras proferidas pelo suposto réu? Diante dessa possibilidade, os doutrinadores do direito dividem os crimes em "materiais" e "formais". ${ }^{8}$ Portanto, sendo de "simples atividade" (Barros, 1990), o crime de racismo se consuma com o agir do sujeito, que pode se dar pela fala e/ou pela veiculação de materiais em livros, internet e/ou cartazes (cf. decisão do STJ, 2012). Esta última possibilidade está prevista no parágrafo $2^{\circ}$ do citado artigo 20: "Se qualquer dos crimes previstos no caput é cometido por intermédio dos meios de comunicação social ou publicação de qualquer natureza. Pena: reclusão de dois a cinco anos e multa". E mais: se o "crime doloso" é aquele no qual o autor tem a intenção de cometer o previsto em lei como ato desviante, o "culposo" é aquele no qual não há a intenção por parte do agente com relação ao resultado. Dessa forma, para que se caracterize a ação criminosa racista há necessidade de que o dolo contorne a conduta do réu.

Dito isto, dos 9 julgamentos por nós analisados, todos fazem menção às duas categorias nativas do discurso jurídico e legal do "dolo" e das "provas" para majoritariamente condenar o(a) acusado(a) de crime de racismo (em 6 julgamentos), mas também para absolvê-lo(a) (em 3 julgamentos). Passemos, então, à compreensão daqueles que absolveram os réus.

No acórdão $n^{\circ}$ IX, o réu foi absolvido sob o argumento de desclassificação para injúria qualificada, uma vez que não ficou caracterizado ou provado o "dolo" indispensável ao crime de racismo. Nas duas outras absolvições, ou seja, nos acórdãos I e VII, a "atipicidade do fato" ou a não caracterização do delito se 
deu pela "ausência de provas", não havendo nem o movimento de desclassificação para injúria qualificada prevista no artigo 140, parágrafo $3^{\circ}$ do Código Penal.

A título de ilustração, detalhemos o julgamento I, envolvendo Herbis Gonçalves e José Rubens da Silva. No dia 19 de novembro de 2003, o réu Herbis, radialista e jornalista, em meio ao seu programa de rádio na cidade de Ribeirão Preto, disse sobre o Sr. Rubens, funcionário da prefeitura municipal, que "tinha que mandar esse cara expulsar esse nego daí, tá ganhando dinheiro do povo e mentindo pro povo" (TJSP, 2012b: 03). O desembargador relator, Antônio Luiz Pires Neto, faz remissão à súmula 7 do Superior Tribunal de Justiça (STJ), que demanda para a caracterização do crime de racismo o dolo específico, e ato contínuo decreta que a conduta do réu "não foi orientada pelo elemento subjetivo típico do racismo, em tom discriminatório voltado contra um grupo social em seu todo, mas, sim, dirigida em relação a pessoa determinada; e, ainda nada indica que essa expressão teria sido usada pelo radialista para referir-se à cor da pele da vítima" (Idem: 04). Constatamos assim que o "nego" proferido e admitido pelo réu contra Rubens, aos olhos do relator, não se vincula à cor da pele da vítima. Ao mesmo tempo observamos, tal como no TJRS, a desarticulação entre honra subjetiva e pessoal e honra coletiva.

O julgamento VII envolve Anna Cristina Cataudella e Carmem do Socorro Guilherme, com a primeira tendo chamado a segunda de "negra imunda", "negra macumbeira", "ladrona" e "drogada" em meio a uma compra de fantasia de carnaval. Sem informação quanto à data do evento no corpo do acórdão, o relator Ricardo Cardozo de Mello Tucunduva absolveu Anna, pois no seu entender, amparado no parecer do procurador de Justiça (promotor do TJSP), "as expressões supra referidas, proferidas em meio a uma acalorada discussão entre Anna e Carmem, indicaram, tão-só, o propósito da primeira em injuriar, de alcançar a honra subjetiva da segunda, sem nenhuma discriminação de raça ou de religião" (TJSP, 2012c: 181).

Para além das costuras por nós já realizadas quanto à estratégia de desvincular a honra subjetiva da coletiva, cujos contornos são similares aos da pesquisa efetuada no TJRS, o que nos parece interessante é que a ausência de provas passa pela inferência absolutamente subjetiva do magistrado ao afirmar que não há em dadas palavras conotação discriminatória ou racista. Então, se não houve testemunhas, incoerência na não confissão do réu, confissão do réu, materialidade posta em cartazes ou veiculação grafada no mundo virtual, dificilmente o crime de racismo se consuma. Ao contrário, nos parece, do crime de injúria, que dispensa tanto quanto (em tese) o de racismo a materialidade para além das palavras (ao vento). Mas mais do que isso, nos parece interessante não descolarmos esta pesquisa de pesquisas futuras que deverão se debruçar sobre a trajetória pessoal e intelectual desses operadores do direito. 


\section{Simone Becker e Deborah Guimarães Oliveira}

\section{Relembrar é (re)conhecer: linhas teóricas e retrospecto quanto à formação das faculdades de direito no século XIX}

O trabalho clássico do sociólogo Sérgio Adorno $(1988 ; 2005)$ esmiúça o quanto nossa intelligentsia jurídica/científica se formou como autoritária e avessa à democracia. Nessa esteira de pesquisa, outro trabalho tradicional é o da antropóloga Lilia M. Schwarcz. Em O espetáculo das raças (1993), Schwarcz sinaliza, em meticulosa análise documental, as influências teóricas que sustentaram (e sugerimos que sustentam) as fundações sobre as quais emergiram metafórica e literalmente os dois cursos de direito no Brasil: o de Recife e o de São Paulo, o do norte e o do sul, no início da década de 20 do século XVIII.

O curso de Recife até 1920 via na raça (e por conseguinte na criminalidade) os males da involução e dos obstáculos ao progresso de nossa nação. Bebendo em autores caros à criminologia positivista, essa an tropologia criminal se sustenta(va), através de Silvio Romero, em Lombroso, Ferri e Garofalo. Esse era o foco das constantes produções da Revista Acadêmica da Faculdade de Direito de Recife (RAFDR). Os argumentos de cunho racista, enquanto determinantes biológicos, ganhavam nuances nas classificações lombrosianas.

Para alguns teóricos, o tipo físico do criminoso era tão previsível que seria possível delimitá-lo de forma objetiva. Lombroso, por exemplo, criou uma minuciosa tabela, subdividida em: "elementos anathomicos" (assimetria cranial e facial, região occipital predominante sobre a frontal, fortes arcadas superciliares e mandíbulas além do protagonismo); "elementos physiologicos" (insensibilidade, invulnerabilidade, mancinismo e ambidestria); "elementos psycologicos" (tato embotado, olfato e paladar obtusos, visão e audição ora fracas ora fortes, falta de atividade e de inibição); e "elementos sociológicos" (existência de tatuagens pelo corpo)". (Schwarcz, 1993: 166).

Após 1920, a raça deixou de ser o foco exclusivo das preocupações da RAFDR, e do próprio ensino na Faculdade de Recife, para abrir alas ao discurso higienista. Não somente a raça, mas a pobreza, o analfabetismo e outros vetores de cunho determinista social ganharam espaço. Isso não quer dizer que a perspectiva racista posta nos teóricos da criminologia positivista tenha sido abandonada. "Nem tão novo, nem tão velho, o certo é que um momento diferente se anunciava. Ao argumento racial somavam-se agora os dados dos sanitaristas, os modelos educacionais, a interpretação dos folcloristas" (Schwarcz, 1993: 172). 
Quanto à escola paulista, as diferenças em relação à recifense são anotadas por Schwarcz, mas o resultado é um implícito racismo posto nos egressos da Faculdade de São Paulo que ocuparam cargos políticos e aprovaram legislações contra a imigração de chineses e africanos, com um viés liberal autoritário e não democrático. No que toca às diferenças, a antropóloga acentua a língua exigida nas duas faculdades: na de Recife, o inglês, o alemão e o italiano, e na paulista, apenas o inglês. Isso demarcava notoriamente as leituras a serem feitas pelos futuros bacharéis. Se na escola paulista a filosofia e o direito civil eram proeminentes, na recifense tratava-se de privilegiar a antropologia criminal posta no darwinismo social que se misturava à criminologia positivista de Lombroso, Ferri e Garofalo.

Nesse sentido, se a Revista da Faculdade de Direito de São Paulo (RFDSP) não era necessariamente o cartão de visitas da própria instituição, tal como ocorria em Recife, as ideias paulistas eram veiculadas nos jornais e legislações. Destacamos, então, um excerto do Correio Paulistano de 19 de julho de 1892:

O que são os chineses... os escravos com todos os horrores e vícios não foram tão perniciosos como a contratação dos chineses... o negro só sabia ser sensual idiota, sem a menor idéia de religião... Já os chineses são gente lasciva ao último grao, escória acumulada de países de relaxadíssimos costumes... São todos ladrões, jogadores a um grao incompreensível... Admittindo a possibilidade de introduzir esses leprosos de alma e corpo quanto gastará o Estado de São Paulo em cárceres com o aumento de criminalidade (Schwarcz, 1993:185-86).

Cabe abrirmos um parêntese para enfatizar que a tendência de mitigar a existência de racismo nos julgamentos em solo paulista por nós analisados representa quiçá a mescla de um tecnicismo dos egressos das faculdades de direito com a própria crença no mito da democracia racial (Freyre, 1984), a partir da ignorância por parte dos operadores do direito da produção teórica de outras áreas do conhecimento dito "científico". Dessa forma, se insultar um sujeito negro de "negro sujo" não é entendido como racismo, o desconhecimento de como as categorias analítica e êmica da "raça" (Guimarães, 2003) vêm à tona e são articuladas na terra brasilis soma-se às próprias artimanhas presentes na lógica jurídica técnica que atribui importância a se provar com concretude a intenção ("dolo") do ofensor em insultar pejorativamente um negro, graças à sua cor/raça.

Todavia, se até aqui enfatizamos as absolvições, cabe trazer os argumentos principais que condenaram certos sujeitos pela prática racista no TJSP. Tra- 


\section{Simone Becker e Deborah Guimarães Oliveira}

ta-se sinteticamente dos julgamentos de II a VI e o VIII. O movimento que faremos é ainda o de enfatizar nessas condenações como o dolo e as provas são tratados pelos julgadores.

\section{Dolo e provas: argumentos que condenam no TJSP}

Waldemar Moreno Rodrigues foi condenado pelo crime de racismo descrito no artigo 14 da Lei 7.716/89 como "impedir ou obstar, por qualquer meio ou forma, o casamento ou convivência familiar ou social" (TJSP, 2012d: 5). No dia 21 de novembro de 1999, o acusado, com arma na mão e acompanhado de "um magote de indivíduos", invadiu a casa da vítima atrás da filha Alessandra aos brados de "esse neguinho não namora minha filha!". Muito embora o réu tenha contestado a alegação de racismo por meio do recurso de "apelação" arguindo que havia recebido a notícia do sequestro da filha maior de idade, os três desembargadores (com parecer no mesmo sentido da Procuradoria da Justiça) consentiram que "o acervo probatório, enfim, retirou à Defesa toda a esperança de ver proclamada a inocência do réu neste pretório da Justiça; é-lhe impossível, portanto, a absolvição" (TJSP, 2012d: 7). A punição de Waldemar no acórdão VI foi substituída por prestação de serviços à comunidade, aos 30 dias do mês de setembro de 2007, com a participação de testemunhas, incluindo a filha do acusado que se contradisse em seus depoimentos.

No acórdão V, Mei Fewg Xia foi punida por ter negado trabalho à vítima sob o argumento de que "neguinha não, neguinha, não" (TJSP, 2012e: 125). Incursa no artigo $4^{\circ}$ da Lei 7.716/89 - "negar ou obstar emprego em empresa privada" -, a acusada negou o fato, dizen do que "não compreende o idioma e nem o significado da palavra 'nega'." O argumento não foi aceito pelos desembargadores, uma vez que:

ficou demonstrado pelo quadro probatório que havia uma vaga aberta e que estava tudo acertado antes do encontro pessoal com a vítima, quando a apelante, ao ver da candidata, aos gritos de "neguinha não, neguinha não", negou-lhe o emprego em sua lanchonete somente em razão de sua cor, de modo que bem configurado o crime de racismo, está justificada a condenação (TJSP, 2012e: 126).

Para além dos testemunhos da vítima e da ré, Viviane, prima da ofendida, também testemunhou alegando que frequentava o comércio de Mei e que ela falava fluentemente o português. Em suma, ao ser condenada, sua punição res- 
tritiva de liberdade foi substituída pela prestação de serviços à comunidade conforme o artigo 44 do Código Penal.

Ainda segundo o que prescreve o artigo $4^{\circ}$ da Lei Caó, o recrutador da empresa Nipomed, Munehiro Tahara, foi condenado por ter obstado acesso a Neusa dos Santos Nascimento e Gisele Ana Ferreira à concorrência a emprego na citada farmácia. Ambas testemunharam conforme consta no acórdão VIII, e, para além delas, Isabel Cristina Lazzarin, que fora recrutada na empresa, sendo amiga da vítima Isabel. Somados os testemunhos das três mulheres, o depoimento do acusado esteve recheado de contradições e, então, conforme destacou o relator:

Está induvidosamente caracterizado o crime em questão, mesmo porque as afirmações do acusado, diga-se, foram diferentes umas das outras, pois quando interrogado na polícia disse que sequer tivera contato com as vítimas e em Juízo, mudando, como que da água para o vinho, disse ter atendido pessoalmente as vítimas e que se recordava nitidamente, de uma delas (TJSP, 2012f: 5).

Por fim, a condenação não pôde ser aplicada porque houve prescrição da punibilidade, isto é, como o julgamento excedeu o tempo de quatro anos, nenhuma punição poderia recair sobre o réu.

Com base no artigo 20, parágrafo $2^{\circ}$, da Lei Caó, Eduardo Brandão Jarussi, Rogério Costa Andrade e Emerson de Almeida Chieri foram condenados no acórdão IV por incitarem, praticarem e induzirem ao racismo na capital paulista. No dia 23 de outubro de 2006, por volta das $0: 35$ h, os acusados colaram cartazes na esquina da avenida Lins de Vasconcelos com Professor Noé Azevedo na Vila Mariana com os seguintes dizeres: "Hoje eles roubam sua vaga nas universidades públicas. Se você não agir agora quem garante que eles não roubarão vagas nos concursos públicos?” (TJSP, 2012g: 449). Como se não bastasse, os cartazes faziam menção ao site www.whitepowersp.org, que veicula fotos de Hitler, o símbolo da suástica e dicas quanto ao melhores horários para a colagem de cartazes com mensagens racistas. De maneira incomum - exceto em casos midiáticos -, o voto do relator foi unanimemente acatado pelos dois outros desembargadores, que não se furtaram a redigir os seus próprios. Em regra, os desembargadores acompanham o voto do relator, sem produzir os seus votos por escrito.

Quanto às provas, as palavras foram substituídas pela materialidade dos cartazes e das testemunhas, transeuntes que passavam pela localidade e acionaram a polícia que prendeu em flagrante os três acusados. Assim, os "condenados foram presos em flagrante portando 184 panfletos e 76 cartazes, todos de cunho 


\section{Simone Becker e Deborah Guimarães Oliveira}

altamente racista" (TJSP, 2012g: 450). No voto da desembargadora não relatora, Angélica de Almeida, aos 19 dias do mês de agosto de 2009, ainda consta a definição ou os pressupostos definidos pelo jurista Guilherme de Souza Nucci ${ }^{9}$ que compõem o artigo 20 da Lei Caó:

O pensamento voltado à existência de divisão dentre seres humanos, constituindo alguns seres superiores, por qualquer pretensa virtude ou qualidade, aleatoriamente eleita, a outros, cultivando-se um objetivo segregacionista, apartando-se a sociedade em camadas e extratos, merecedores de vivência distinta (TJSP, 2012g: 454).

Segundo idêntico artigo da Lei 7.716/89, no acórdão II, a ré Liriam Pereira foi condenada por discriminar a vítima após esta jogar um cigarro em local que acabara de limpar. Assim, "a vítima confirmou os fatos (fl.176) e houve testemunha presencial, que alegou ter pensado que era apenas uma brincadeira o fato de a ré ter dito que 'preto cheira mal, preto não é gente' (fls.127/128), além de outros depoentes que não ouviram as ofensas, mas presenciaram o estado emocional do ofendido logo após, quando ele, aos prantos, relatou versão idêntica" (TJSP, 2012h: 4). Com redução da pena inicialmente atribuída à ré, o relator Tristão Ribeiro, aduziu que "já estão englobadas pela tipicidade do delito em foco, que já é muito mais grave do que a injúria racial, por exemplo, não podendo embasar a fixação das básicas no dobro do piso, como verificado na sentença” (TJSP, 2012h: 5). Torna-se importante destacar que ao mencionar a injúria qualificada pelo teor racial, a diferenciação entre esta e o crime de racismo posto no artigo 20 da Lei Caó é tecida nos seguintes termos, com base na obra dos juristas José Geraldo da Silva, Wilson Lavorenti e Fabiano Genofre:

A diferença entre este crime e a injúria prevista no art. $140, \S 3^{\circ}$, do Código Penal, reside no fato de que neste o agente quer ofender a honra da pessoa com a qual teve algum tipo de alteração e o faz por intermédio de referência à sua cor, raça, etnia, religião ou origem. Já no crime do art. 20, o agente evidencia preconceito ou discriminação contra toda uma raça, cor, etnia, religião ou procedência nacional, ainda que manifestada na presença e desfavor de uma pessoa (TJSP, 2012h: 5).

Nota-se, em suma, a diferenciação de Guilherme Nucci pautada na separação entre honra subjetiva e coletiva - algo que talvez sinalize uma implícita reiteração do "mito da democracia racial", ou ainda a sutileza de como o racismo se impregna em meio às nossas relações sociais. 
Análise sobre a (não) caracterização do crime de racismo no TJSP

\section{Considerações finais}

A análise sistemática e pormenorizada dos acórdãos produzidos pelo TJSP, aqui apresentada, conduz à reflexão sobre os argumentos que levam seus discursos jurídicos a não criminalizar como racismo condutas ofensivas aos negros, assim como sobre os argumentos que condenam pela prática do mesmo crime.

Lembramos que a pesquisa esteve voltada para o rastreamento das principais repetições de justificativas, que condenam ou absolvem, nos acórdãos produzidos pelo TJSP. Dessa forma destacamos: "Crimes formais, dolo e provas", "Honra subjetiva x honra objetiva" e "Substituição de penas" como os enunciados que concedem nuances às absolvições e às condenações do e no tribunal paulista.

Tendo em vista que são três tópicos de grande relevância e extensão, nos ocupamos neste artigo apenas do primeiro tópico. Assim, buscamos analisar as repetições referentes ao dolo e às provas, atingindo indiretamente os crimes formais, classe esta a que pertence o crime de racismo para a classificação êmica do direito penal.

Observamos que dos 9 julgamentos produzidos pelo TJSP e por nós analisados via palavra-chave "crime de racismo" lançada no site de jurisprudências do citado locus, todos se referiram ao "dolo" e às "provas", sendo que em 6 houve condenação, e em 3 absolvição dos réus.

Os argumentos que pautaram a absolvição foram: no acórdão IX, a desclassificação do crime de racismo para o crime de injúria qualificada, uma vez que não ficou caracterizado ou provado o "dolo" indispensável ao crime de racismo; nos acórdãos I e VII, a não caracterização do delito pela "ausência de provas" que (in)diretamente afeta o elemento subjetivo da intenção do sujeito acusado por racismo.

O que nos chamou a atenção foi o fato de que a ausência de provas é um dos argumentos utilizados pelo TJSP para afirmar que não há em dadas palavras conotação discriminatória nem racista, sendo que o crime de racismo (na teoria) é um crime formal, isto é, não necessita de resultado para que se concretize, bastando apenas a atividade do agente, que pode se dar pela fala e/ou veiculação de materiais em livros, cartazes e/ou internet.

Sendo assim, pudemos perceber, pelo discurso do TJSP, que, se não há testemunha, se há coerência nos depoimentos do réu, se não há a confissão do réu ou a materialidade veiculada em cartazes e/ou internet, dificilmente o crime de racismo se consuma.

Entretanto, cabe (com reticências e sem pontos finais) relativizar dois aspectos que nos saltaram aos olhos no tocante à visibilidade dos crimes de racis- 


\section{Simone Becker e Deborah Guimarães Oliveira}

mo no contexto do TJSP, a despeito do já esmiuçado quanto às desclassificações e às absolvições. $\mathrm{O}$ primeiro centra-se na disparidade (para mais) dos percentuais de condenações em relação às absolvições e na significativa quantidade de demandas que vieram à tela, ora quando a palavra-chave digitada por nós foi "crime de racismo" (599), ora quando a palavra-chave foi "condenação crime de racismo" (321), ora quando filtramos para a área criminal (249). De per si tais percentuais (de condenação) e números nos fazem refletir sobre a possiblidade de uma "cultura jurídica"10 (Santos, 1996, 1996a) mais receptiva às reivindicações de acesso a direitos de minorias historicamente marcadas pelos preconceitos raciais. Quiçá, uma cultura jurídica menos afetada pela cegueira cara à sua lógica, que, sob a influência da "tradição iluminista, tem grande dificuldade em considerar práticas e valores locais - o que impede o tipo de diálogo criativo entre princípios gerais e práticas locais, esperado pelos idealizadores dos documentos de direitos humanos internacionais" (Fonseca, 2004: 114). Esperado não apenas por esses idealizadores, mas, sobretudo, por nós, sujeitos de carne e osso que vivenciamos as mais diversas relações sociais atravessadas por vetores como os da etnia e/ou da raça.

\section{Anexo}

Numeração dos julgamentos ou acórdãos

\begin{tabular}{ccl}
\hline $\begin{array}{l}\text { Número veiculado no } \\
\text { corpo do trabalho }\end{array}$ & Número original da apelação & Resultado \\
\hline I & $0125373-37.2006 .8 .26 .0000$ & Absolvição \\
II & $990.10 .154240-4$ & Condenação \\
III & $990.08 .042442-4$ & Condenação \\
IV & $990.08 .180555-3$ & Condenação \\
V & $856.085-3 / 5$ & Condenação \\
VI & $429.977-3 / 7-00$ & Condenação \\
VII & $483.151 .3 / 3-00$ & Absolvição \\
VIII & $313.895-3 / 1-00$ & Condenação \\
IX & $273.847 .3 / 0-00$ & Absolvição \\
\hline
\end{tabular}


Análise sobre a (não) caracterização do crime de racismo no TJSP

Notas

1. A pesquisa do PIVIC foi desenvolvida entre 2010 e 2011, e o projeto de pesquisa englobante tem vigência de 2011 a 2015. Salientamos que em ambos houve a participação dos colegas discentes Glédyson Ferreira dos Santos e Débora Batista Miranda, cujas contribuições resultaram em outros projetos de pesquisa.

2. O decurso do tempo não faz cessar o poder-dever do Estado de punir o indivíduo. Ou seja, o Estado terá para sempre o poderdever de punir aqueles indivíduos que praticam o crime de racismo, em quaisquer das suas tipificações legais contidas na Lei 7.716/89.

3. Não é possível o réu pagar certa quantia em dinheiro, a "fiança", para responder ao processo em liberdade. Entretanto, há que existir a prisão em flagrante delito, ou seja, o ofensor deve ser preso em seguida ao cometimento da conduta "criminosa".

4. Acórdão é a decisão do órgão revisor colegiado de um tribunal, referente aos recursos interpostos pela parte ou por terceiros interessados contra as decisões proferidas por um órgão monocrático, isto é, que foi o primeiro a pôr um fim provisório ao conflito.

5. Grosso modo, o "direito alternativo" foi encampado pelos "operadores do direito" - juízes, promotores, etc. - com o objetivo (maior) de denunciar o tecnicismo (da prática jurídica) ligado à mera subsunção legal de casos concretos.
6. A ênfase no estado do Mato Grosso do Sul se dá pelo fato de que uma das autoras desenvolve pesquisa sobre crimes de racismo envolvendo indígenas nessa região.

7. Doutrina é o nome que se dá nas "ciências jurídicas" aos artigos, obras escritas por juristas ou teóricos responsáveis pela interpretação das legislações. A título de apontamento, é interessante observarmos que a significação primeira do termo "doutrina" nos remete aos discursos herméticos litúrgicos, em meio aos quais a "verdade" tende a emergir como singular, ao invés de plural.

8. A diferença entre esses dois tipos de crimes é que nos crimes materiais há necessidade de resultados naturalísticos para que eles se consumam, como no homicídio. No caso dos crimes formais, diferentemente dos crimes de mera conduta (p. ex., insulto à honra), há previsão do resultado, mas o resultado não é exigido. Nos crimes de mera conduta, não há previsão nem exigência de resultado.

9. Este é o teórico do direito responsável por desvincular a honra individual da coletiva.

10. Ao nos reportarmos ao conceito de cultura jurídica referimo-nos a um dado campo do conhecimento que é regido por normas e práticas particulares. 


\title{
Simone Becker e Deborah Guimarães Oliveira
}

\author{
Referências bibliográficas
}

ADORNO, Sérgio et al. O que é pesquisa em Direito? São Paulo: Quartier Latin, 2005. p.109-118.

Os aprendizes do poder. Rio de Janeiro: Paz e Terra, 1988.

ARANTES, Rogério Bastos. Direito e política: o Ministério Público e a defesa dos direitos coletivos. Revista Brasileira de Ciências Sociais (RBCS), vol.14, n.39, fev. 1999. p.83-102.

BARROS, Orlando Mara de. Dicionário de classificação de crimes. $5^{\text {a }}$ ed. Rio de Janeiro: Liber Juris, 1990.

BECKER, Simone. Honras E $\mathcal{E}$ estratégias: formas de ser mulher no bairro das Flores. (Dissertação de mestrado) Programa de PósGraduação em Antropologia Social, Universidade Federal do Paraná, Curitiba, 2002.

Dormientibus non socurrit jus! (O direito não socorre os que dormem!) - Um olhar antropológico sobre ritos processuais judiciais (envolvendo o pátrio poder/poder familiar) e a produção de suas verdades. (Tese de doutorado em Antropologia Social) Programa de Pós-Graduação em Antropologia Social, Universidade Federal de Santa Catarina, Florianópolis, 2008.

BONFIM, Juliana Sanches S. Colonização particular: atuação da companhia viação São Paulo - Mato Grosso (1940-1960). (Dissertação de mestrado) Programa de Pós-Graduação em História da UFGD, 2009.

BOURDIEU, Pierre. Esquisse d'une theorie de la pratique, précédée de trois études d'ethnologie Kabyle. Genève/ Paris: Libraire DROZ, 1971.

Razões práticas: sobre uma teoria da ação. Campinas: Papirus, 1996.
CARRARA, Sérgio. Crime e loucura. O aparecimento do manicômio judiciário na passagem do século. Rio de Janeiro: Eduerj/ São Paulo: Edusp, 1998.

DA MATTA, Roberto. Relativizando: uma introdução à antropologia social. Petrópolis: Vozes, 1981.

DUMONT, Louis. Homo hierarchicus: o sistema de castas e suas implicações. $2^{\mathrm{a}}$ ed. São Paulo: Edusp, 1997.

FONSECA, Cláudia. Família, fofoca e honra: etnografia de relações de gênero e violência em grupos populares. Porto Alegre: Editora da Universidade Federal do Rio Grande do Sul, 2000.

. Os direitos da criança - dialogando com o ECA. In: FONSECA, Cláudia; TERTO JR., Veriano e ALVES, Caleb Faria (orgs.). Antropologia, diversidade e direitos humanos. Diálogos interdisciplinares. Porto Alegre: Editora da UFRGS, pp.103-116, 2004.

FREYRE, Gilberto. Casa grande $\mathcal{E}$ senzala. Rio de Janeiro: Record, 1998.

GUIMARÃES, Antonio Sérgio Alfredo. Como trabalhar com "raça" em sociologia. Educação e Pesquisa, v. 29, n. 1, jan./jun. São Paulo: Unicamp, 2003. p.93-107.

Lei 7.716/89 - Lei Caó. Disponível em: http://www.planalto.gov.br/ccivil_03/leis/1 7716.htm. Acesso em: abril de $20 \overline{1} 2$.

LEITE, Ilka Boaventura. Antropologia da viagem: escravos e libertos em Minas Gerais no século XIX. Belo Horizonte: Editora UFMG, 1996.

MALINOWSKI, Bronislaw. Os argonautas do Pacífico ocidental. São Paulo: Abril, 1978. 
PANICE, Luciene Seribelli. O crime de racismo no Brasil. (Trabalho de conclusão de curso) Universidade de Franca, 2009.

PITT-RIVERS, Julian. Antropologia del honor o politica de los sexos: ensayo de antropologia mediterránea. Barcelona: Editorial Crítica, 1979.

ROCHA, Emerson Ferreira. Cor e dor moral. In: SOUZA, Jessé José Freire (org.). $A$ ralé brasileira: quem é e como vive. Belo Horizonte: Editora UFMG, 2009.

SADEK, Maria Tereza et alii (orgs.). Magistrados: uma imagem em movimento. Rio de Janeiro: Editora FGV, 2006.

SANTOS, Boaventura de Souza. Pela mão de Alice. O social e o político na pós-modernidade. $2^{\mathrm{a}}$ ed. São Paulo: Editora Cortez, 1996.

Os tribunais nas sociedades contemporâneas: o caso português. Porto: Edições Afrontamento, 1996a.

SCHWARCZ, Lilia M. O espetáculo das raças: cientistas, instituições e questão racial no Brasil 1870-1930. São Paulo: Companhia das Letras, 1993.

SILVA, Cátia Aida. Fustiça em jogo. São Paulo: Edusp, 2001.

Promotores de justiça e novas formas de atuação em defesa de interesses sociais e coletivos. Revista Brasileira de Ciências Sociais (RBCS), vol. 16, n. 45, fev. São Paulo: ANPOCS, 2001. p. 127-144.

STJ (2012). Superior Tribunal de Justiça. Disponível em: www.stj.jus.br/portal sti/publicacao/engine.wsp?tmp.area $=398$ 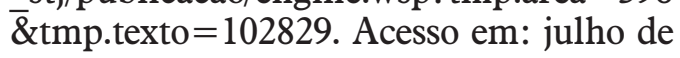 2012.
TJSP. (2012a). Apelação criminal sob n. 990.08.042442-4. Disponível em: http:// esaj.tjsp.jus.br/cjsg/getArquivo.do?cdAcor dao $=4778045$. Acesso em: abril de 2012.

TJSP, (2012b). Apelação criminal sob n. 0125373-37.2006.8.26.0000. Disponível em: http://esaj.tjsp.jus.br/cjsg/getAr quivo.do?cdAcordao = 5362886. Acesso em: abril de 2012.

TJSP, (2012c). Apelação criminal sob $\mathrm{n}$. 483.151.3/3-00. Disponível em: http:// esaj.tjsp.jus.br/cjsg/getArquivo.do?cdAcor dao $=2238079$. Acesso em: abril de 2012 .

TJSP, (2012d). Apelação criminal sob n. 429.977-3/7-00. Disponível em: http:// esaj.tjsp.jus.br/cjsg/getArquivo.do?cdAcor dao $=2380214$. Acesso em: abril de 2012.

TJSP, (2012e). Apelação criminal sob n. 856.085-3/5. Disponível em: http://esaj. tjsp.jus.br/cjsg/getArquivo.do?cdAcordao $=2476946$. Acesso em: abril de 2012 .

TJSP, (2012f). Apelação criminal sob $\mathrm{n}$. 313.895-3/1-00. Disponível em: http://esaj. tjsp.jus.br/cjsg/getArquivo.do?cdAcordao $=1957868$. Acesso em: abril de 2012 .

TJSP, (2012g). Apelação criminal sob $\mathrm{n}$. 990.08.180555-3. Disponível em: https:// esaj.tjsp.jus.br/cjsg/getArquivo.do?cdAcor dao $=4192274$. Acesso em: abril de 2012.

TJSP, (2012h). Apelação criminal sob n. 990.10.154240-4. Disponível em: https:// esaj.tjsp.jus.br/cjsg/getArquivo.do?cdAcor dao $=4835481$. Acesso em: abril de 2012.

VIANNA, Luiz Werneck et alii. Corpo e alma da magistratura Brasileira. Rio de Janeiro: Revan, 1997.

\section{Resumo}

No presente artigo trazemos à tona por meio da análise discursiva os principais argumentos que levam os discursos jurídicos do TJSP a (não) 


\section{Simone Becker e Deborah Guimarães Oliveira}

criminalizar como racismo condutas ofensivas aos(às) negros(as). Para que haja crime de racismo, a estratégia do discurso jurídico é de desvincular a honra individual da coletiva, tornando condenáveis aqueles que insultam a raça negra como um todo, e não um sujeito negro. Além desta estratégia, a coerência da concretude probatória dos xingamentos e a intenção dos ofensores são destacadas como imprescindíveis à caracterização do crime de racismo.

Palavras-chave: análise de discurso; crimes de racismo; TJSP.

\section{Abstract}

This article shows, through discursive analysis, the main arguments that lead the TJSP decisions (not) to criminalize as racism conducts that are offensive to black people. In order to recognize crime of racism, the strategy of legal discourse is to disconnect the individual honour from the collective one, and condemn those who insult the black race as a whole, and not just a black person. Besides this strategy, the coherence of the probative concreteness of curses and the intention of offenders are pointed as essential to the characterization of the crime of racism.

Keywords: discourse analysis; racism crimes; TJSP.

\section{Résumé}

Cet article montre, à travers l'analyse du discours, les principaux arguments qui font les discours juridiques du TJSP (ne pas) criminaliser comme racisme des conduites offensives aux noirs. Pour qu'il y ait crime de racisme, la stratégie du discours juridique consiste à distinguer l'honneur individuel de l'honneur collectif et à condamner ceux qui insultent pas un individu noir, mais la race noire. À côté de cette stratégie, la cohérence des preuves concrètes des offenses et l'intention des offenseurs sont considérées essentielles à la caractérisation du crime de racisme.

Mots clés: analyse de discours; crimes de racisme; TJSP. 